\title{
Thunderstorms over a tropical Indian station, Minicoy: Role of vertical wind shear
}

\author{
H S Chaudhari ${ }^{1, *}$, G K SAwaisarje 2 , M R Ranalkar ${ }^{2}$ and P N Sen ${ }^{3}$ \\ ${ }^{1}$ Indian Institute of Tropical Meteorology, Pune 411008 , India. \\ ${ }^{2}$ India Meteorological Department, Pune 411 005, India. \\ ${ }^{3}$ Department of Atmospheric and Space Sciences, University of Pune, Pune 411 007, India. \\ *e-mail: hemantkumar@tropmet.res.in
}

In this study, an attempt has been made to bring out the observational aspects of vertical wind shear in thunderstorms over Minicoy. Case studies of thunderstorm events have been examined to find out the effect of vertical wind shear and instability on strength and longevity of thunderstorms. Role of vertical wind shear in thunderstorms and its mechanism has been explored in this study. Results reveal that for prolonged thunderstorms high and low instability along with moderate to high vertical wind shear (moderate: $0.003 \mathrm{~S}^{-1} \leq$ vertical wind shear $\leq 0.005 \mathrm{~S}^{-1}$ and high: $>0.005 \mathrm{~S}^{-1}$ ) play a significant role in longevity and strength of thunderstorms. The mechanism of vertical wind shear in thunderstorms was investigated in a few cases of thunderstorm events where the duration of thunderstorm was covered by the radiosonde/rawin ascent observation taken at Minicoy. Empirical model has been developed to classify thunderstorm type and to determine the strength and longevity of thunderstorms. Model validation has been carried out for selected cases. Model could classify thunderstorm type for most of the cases of thunderstorm events over island and coastal stations.

\section{Introduction}

Thunderstorm is defined as one or more sudden electrical discharges, manifested by a flash of light (lightning) and a sharp or rumbling sound (thunder). It is a mesoscale phenomenon which consists of three stages of evolution, namely, cumulus, mature, and dissipating (Byers and Braham 1949). The thunderstorms may be classified as single cell, multicell, squall line and supercell (Browning 1977, 1986). It is well known that conditional instability and vertical wind shear of the atmosphere determine the thunderstorm type (Klemp 1987). Studies have indicated the importance of vertical wind shear in meso-scale systems (Browning and Ludlum 1962; Rao and Mukherjee 1958).

The presence or absence of conditional instability is one of the favourable conditions for occurrence of a thunderstorm and it is deduced from $T-\Phi$ gram (Tephigram). It is quantified by different stability indices. In the present study, Convective Available Potential Energy (CAPE), Convective Inhibition Energy (CINE) and lifted index (LI) have been used for analysis of the thunderstorms. Previous studies (Moncrieff and Miller 1976; Williams and Renno 1993) have highlighted the role of CAPE and CINE in isolated rainfall from mesoscale convective activity. Srivastava and Sinha Ray (1999) have studied the role of CAPE and CINE for occurrence of more convective activities in the month of April 1997. De and Dutta (2005) interpreted CAPE as the maximum amount of potential energy, possessed by air parcel, solely due to convection, convertible to vertical kinetic energy. Sen (2005) has classified the state of atmosphere based on the threshold values of CAPE. Schneider and Sharp (2007) have given

Keywords. Vertical wind shear; thunderstorms; empirical model; CAPE; CINE. 
threshold values for LI and CAPE as applied to the hurricane-spawned tornado.

LI is a useful forecasting tool for the prediction of latent instability (Galway 1956). Importance of wind shear during pre-monsoon season is also reported by Basu and Mondal (2002). They have shown that low-to-moderate wind shear in the layer $1.5-3.1 \mathrm{~km}$ and moderate-to-large wind shear in layers below and above this layer are favourable for occurrence of thundersqualls over Calcutta. Weisman and Klemp (1982) pointed out that modeled thunderstorms growing in an environment of moderate shear (i.e., $3 \times 10^{-3} \mathrm{~s}^{-1}$ to $5 \times 10^{-3} \mathrm{~s}^{-1}$ ) show an increasing tendency for organization and supercell characteristics, whereas those growing in an environment of strong shear (i.e., $>5 \times 10^{-3} \mathrm{~s}^{-1}$ ) develop the most persistent and strong mesocyclones. According to Rasmussen and Wilhelmson (1983), environments of low shear and low CAPE are conducive for nonrotating thunderstorms while with moderately strong shear $\left(>3.5 \times 10^{-3} \mathrm{~s}^{-1}\right)$ and high CAPE $(>2500 \mathrm{~J} / \mathrm{kg})$ tornadic storms are sustained. The above-mentioned studies by Weismen and Klemp (1982) and Rasmussen and Wilhelmson (1983) were done for cases of mid-latitude thunderstorms. Present study (based on 162 thunderstorm cases) reports that thunderstorms over Minicoy also show vertical wind shear values in the same order as of mid-latitude storms.

Minicoy $\left(8.30^{\circ} \mathrm{N}, 73.15^{\circ} \mathrm{E}\right)$ is a remote island in southeast Arabian Sea. It has an altitude of 2 meters above mean sea level and a geographical size of $4.4 \mathrm{~km}^{2}$. This island is isolated from other islands of Lakshadweep and lies at a distance of about $410 \mathrm{~km}$ from Kochi, India. During premonsoon months - March to May, this sea area experiences disturbed weather mainly due to synoptic situations like formation of cyclonic storms and depressions, low pressure areas and troughs of low pressure (Ray Choudhary et al 1959; Mukherji et al 1961).

Kandalgoankar et al (2002) have examined thunderstorm activity and Sea Surface Temperature (SST) over the island stations along west coast (Minicoy) of India and found close association with each other which is linked with seasonal establishment of monsoon. Manohar and Kesarkar (2003) have also concluded that south parts of Lakshadweep islands are influenced by thunderstorm activity in association with the convective instability due to summer heating, availability of moisture in preparation for the onset of southwest monsoon. Most of the thunderstorm studies over the Indian region pertain to inland stations. The island stations along west coast (Minicoy) of India experience thunderstorm activities during pre-monsoon months which continue till the onset of southwest monsoon. Thunderstorm activities over Minicoy during pre-monsoon months are one of precursors for the onset of southwest monsoon. In this viewpoint, thunderstorm studies over Minicoy are important.

The main objective of this paper is to investigate characteristics of thunderstorms over Minicoy. In this study thunderstorm classification is done on the basis of wind shear and convective instability. A total of 162 cases of thunderstorms are selected and investigated for finding thresholds of vertical wind shear, CAPE, CINE and LI. The thresholds have been used to develop an empirical model for determining thunderstorm type.

\section{Data and methodology}

Present study utilizes the daily radiosonde/rawin data over Minicoy for the period 1991-2006. The data for March, April and May were obtained from the University of Wyoming (http:// weather.uwyo.edu/upperair/). Information regarding occurrence of thunderstorms was obtained from India Meteorological Department (IMD).

Vertical wind shears in all the layers of the atmosphere at 0000 UTC and 1200 UTC during the days when thunderstorms occurred have been computed using formula:

$$
\mathrm{VWS}_{2-1}=\frac{\sqrt{\left(u_{2}-u_{1}\right)^{2}+\left(v_{2}-v_{1}\right)^{2}}}{z_{2}-z_{1}} \mathrm{~s}^{-1},
$$

where, $\mathrm{VWS}_{2-1}$ is vertical wind shear between lower level (1) and upper level (2); $u_{2}, u_{1}$ indicate zonal component of wind at (2) and (1), respectively; $v_{2}, v_{1}$ indicate meridional component of wind at (2) and (1), respectively; $z_{2}, z_{1}$ indicate height of (2) and (1), respectively.

Thunderstorm events having wind profile up to $200 \mathrm{hPa}$ are considered for computation of mean vertical wind shear in atmospheric layer (surface to $700 \mathrm{hPa}$ and $500 \mathrm{hPa}$ to $200 \mathrm{hPa}$ ). We define mean low layer wind shear (LLWS) per $\mathrm{km}$ as the average of vertical wind shear in all layers between surface and $700 \mathrm{hPa}$. Similarly, we define mean upper layer wind shear (ULWS) per $\mathrm{km}$ as the average of vertical wind shear in all layers between 500 and $200 \mathrm{hPa}$. Generally, vertical speed shear and vertical directional shear influence development of the thunderstorm. The zonal $(u)$ and meridional $(v)$ components of wind between surface to $700 \mathrm{hPa}$ and $500 \mathrm{hPa}$ to $200 \mathrm{hPa}$ are considered to account both vertical speed shear and vertical directional shear. The vertical wind shear can be taken as a suitable stability index to 
analyze thunderstorm events. Vertical wind shear difference per km (VWSD) is defined as the difference between ULWS and LLWS.

Many authors have defined the threshold values for convective instability and wind shears (Sen 2005; Weismen and Klemp 1982). Weisman and Klemp (1982) have suggested weak shear as less than $0.003 \mathrm{~s}^{-1}$, strong shear as greater than $0.005 \mathrm{~s}^{-1}$, and others are considered as moderate shears for mid-latitude thunderstorms. After analyzing 162 cases of thunderstorms over Minicoy we have seen that the vertical wind shear values show same order as of mid-latitude storms. We can take the above cut-off limits to define shears as weak, strong and moderate. Our observation of thunderstorms show a scale on the higher side of moderate and strong shears $\left(0.005 \mathrm{~s}^{-1}\right)$. We have put a critical limit of $2500 \mathrm{~J} / \mathrm{kg}$ for analyzing these 162 cases namely CAPE $<2500 \mathrm{~J} / \mathrm{kg}$ and CAPE $\geq 2500 \mathrm{~J} / \mathrm{kg}$.

\section{Results and discussion}

\subsection{Characteristics of thunderstorm and non-thunderstorm days over Minicoy}

Monthly mean thunderstorm frequency over Minicoy was computed using the available observational surface data of IMD from 1969 to 2008. Monthly mean frequency of thunderstorms for the months of March, April, May and June are 1.64, 5.15, 7.17 and 4.35, respectively. Ranalkar and Chaudhari (2009) have also pointed out that the month of May has maximum frequency of lightning flashes and thunderstorm activity. It is also observed from IMD data that thunderstorm activity during May occur at late night and early morning hours. Mukherjee et al (1983) have shown that both sea breeze as well as land breeze help in triggering thunderstorms in island stations.

Figures 1 and 2 depict the CAPE, CINE, LI on individual thunderstorm events for the categories CAPE $<2500 \mathrm{~J} / \mathrm{kg}$ and CAPE $\geq 2500 \mathrm{~J} / \mathrm{kg}$. Figure 1(c) shows that LI values are centered at -5 . In case of figure 2(c), LI values are centered around -10 . Figure $1(\mathrm{~b})$ shows that on most of the thunderstorm days CINE value reaches more than $-100 \mathrm{~J} / \mathrm{kg}$. But in the case of figure $2(\mathrm{~b})$, there is only one such occasion. It means that in the case of CAPE $>2500 \mathrm{~J} / \mathrm{kg}$, the CAP (negative area on $T-\Phi$ gram) has been overcome and instability continues to build up. However, only under favourable conditions (like low level convergence and upper level divergence, incursion of moisture in lower levels, etc.), thunderstorm occurs. In the case of CAPE $<2500 \mathrm{~J} / \mathrm{kg}$, instability (positive area on $T-\Phi$ gram) is building up and
CAP needs to be overcome. Therefore on most of the thunderstorm days, CINE reaches more than $-100 \mathrm{~J} / \mathrm{kg}$.

The examination of LLWS and ULWS on thunderstorm days and non-thunderstorm days does not show any significant features, but in general, vertical wind shear crosses value $0.005 \mathrm{~s}^{-1}$ on most of the days.

\subsection{Case studies of thunderstorm events}

Five special cases of thunderstorm (during April and May) are considered:

(1) slight or moderate thunderstorm with rain,

(2) slight or moderate thunderstorm with hail,

(3) heavy thunderstorm with rain,

(4) thunderstorm but no precipitation at the time of observation, and

(5) thunderstorm with or without precipitation.

Parameters such as levels of freezing, precipitable water content (PWC), CAPE, CINE and LI of thunderstorm events in April and May are presented in table 1. Average dew point depression (ADPD) in layers of atmosphere during radiosonde/rawin ascent is calculated and presented in table 1 . Table 2 contains the observed parameters namely LLWS, ULWS, VWSD, CAPE, CINE, LI, rainfall, time of commencement of thunderstorm and duration of thunderstorm for these case studies.

Case 1: Thunderstorm of 8 April 1996. On this day, CAPE was $5788 \mathrm{~J} / \mathrm{kg}$ with high negative LI (-10) suggesting the possibility of strong thunderstorm. Vertical wind profile at 0000 UTC over Minicoy is shown in figure 3 . The low value of CINE is also favourable for the development of thunderstorm. It is seen that winds are veering with height. It indicates warm air advection over the station, which is a favourable factor for the occurrence of thunderstorms. Thunderstorm commenced at 0931 UTC and cessation occurred at 1230 UTC. The event was reported at 1200 UTC as moderate thunderstorm with rain. PWC was found $64.49 \mathrm{~mm}$ whereas lifting condensation level (LCL), level of free convection (LFC) and equilibrium level (EL) were $955.23,854.92$ and $150.98 \mathrm{hPa}$, respectively. The freezing level was $592 \mathrm{hPa}$ at a height of $4.540 \mathrm{~km}$. Amount of rainfall was $9.91 \mathrm{~mm}$. ADPD was $2^{\circ} \mathrm{C}$ indicating clouds are in unbroken form. VWSD between ULWS and LLWS was positive which indicated the suppression of deep development of updrafts. Thus, thunderstorm lasted only for 1.8 hours.

Case 2: Thunderstorm of 13 May 1992. On this day at 0000 UTC, the event was reported as 


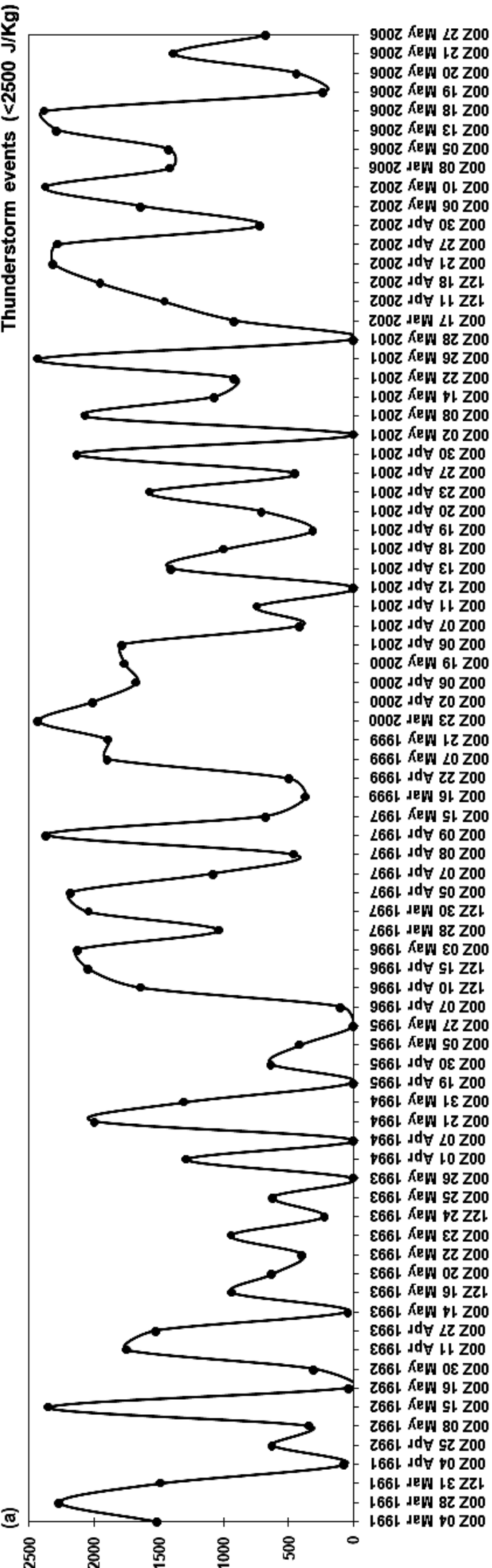

(6)्राr) $\exists d \forall ว$

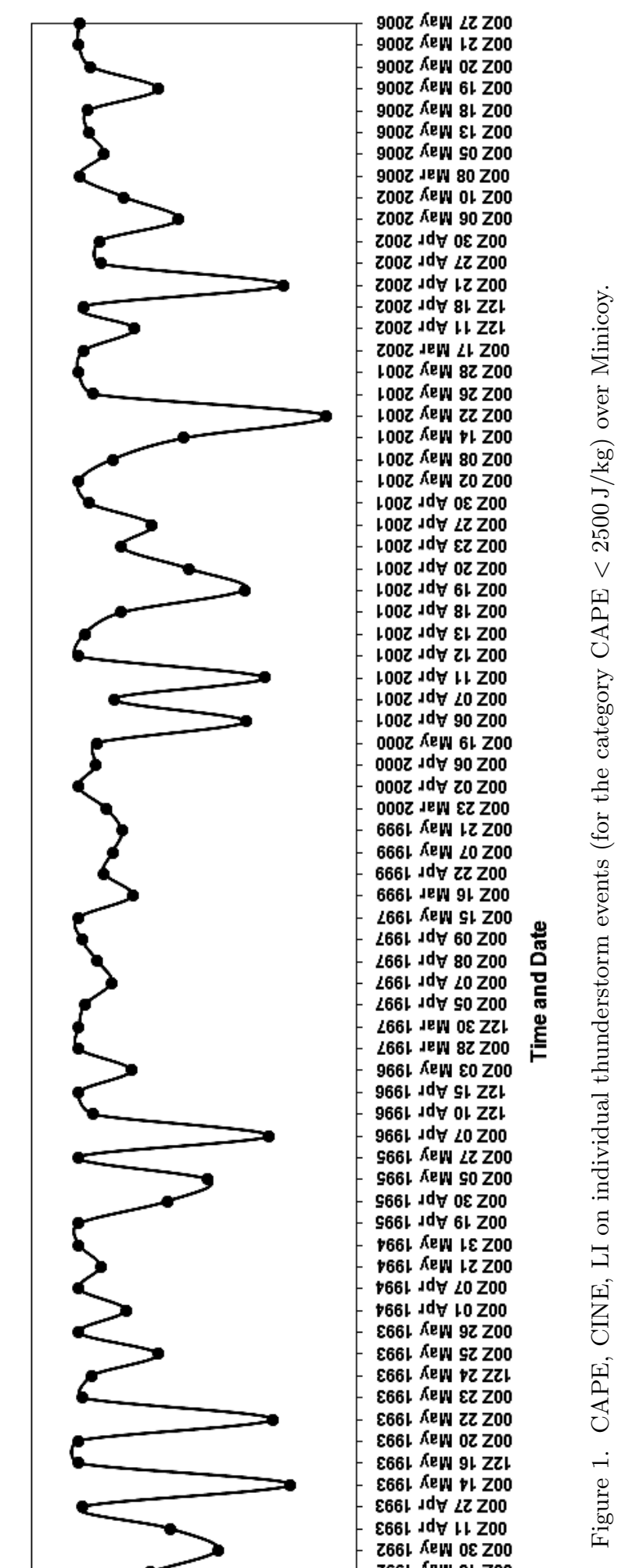

a

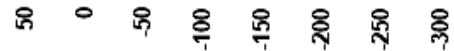

(Б)પ्रIr) ヨNIว 


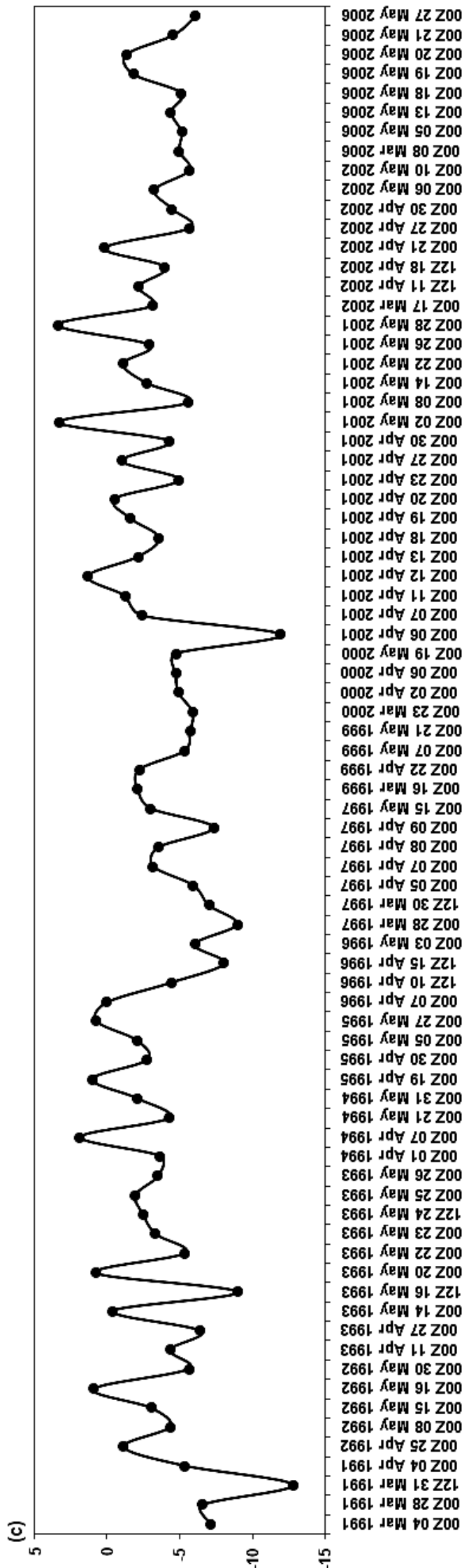

(Iา) хәрu| pәџ!

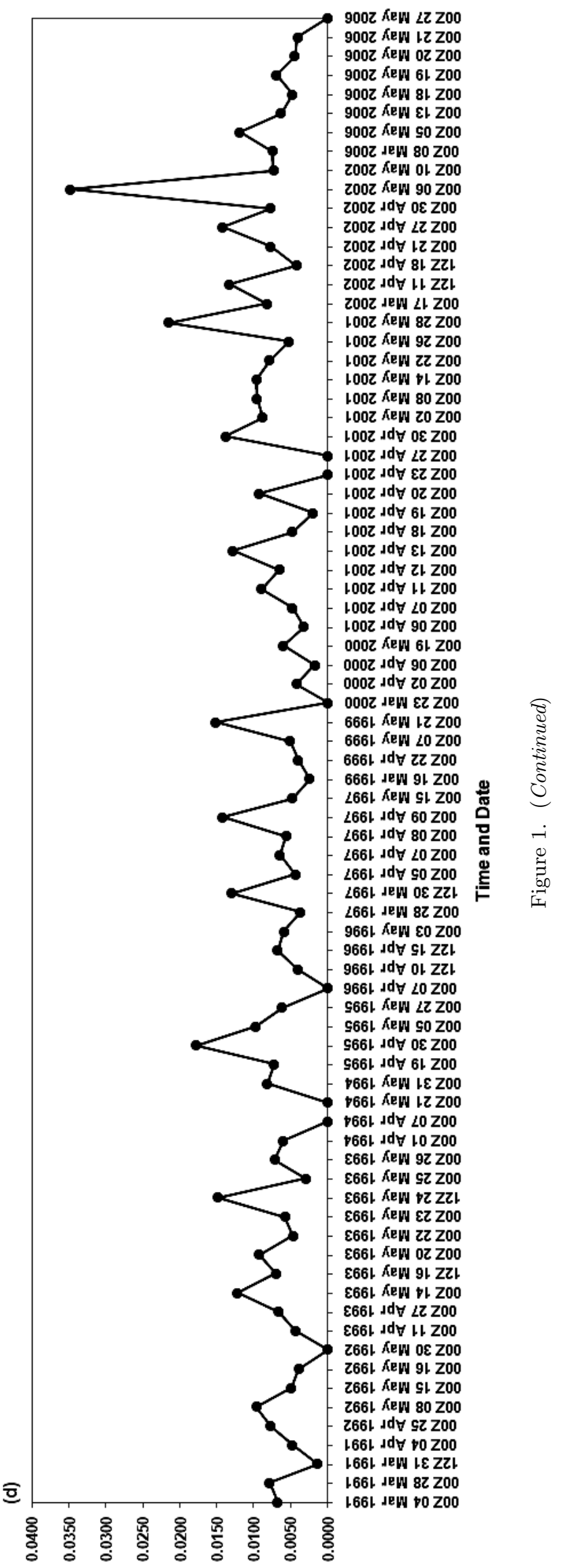

SMา7 


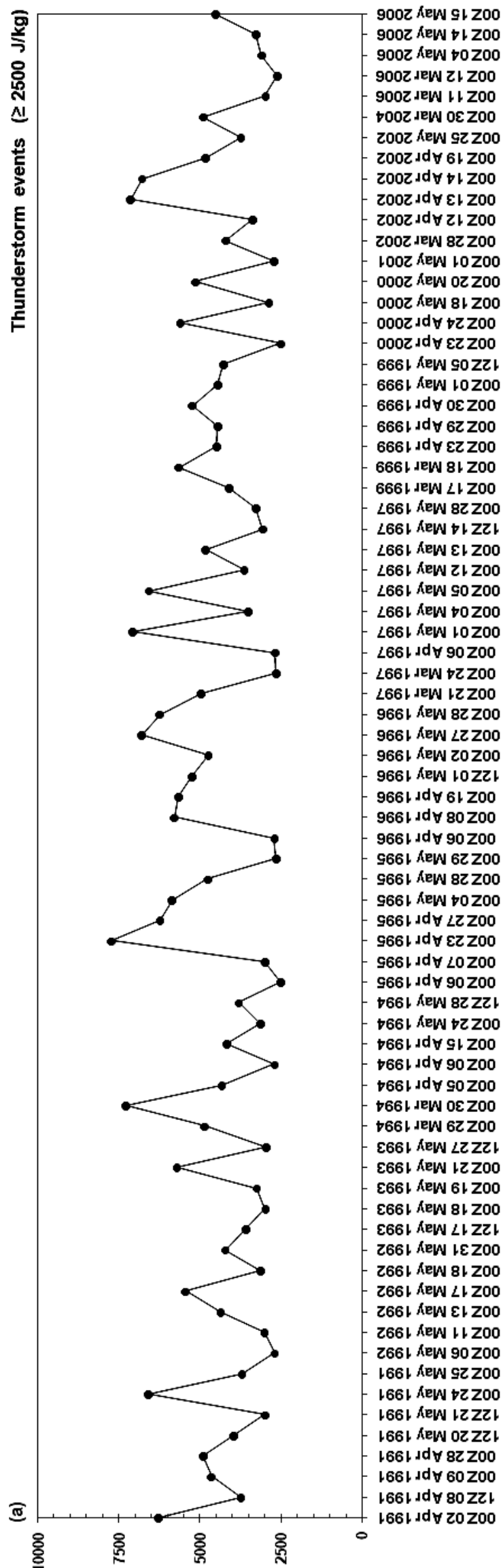

(6)्रा $\exists d \forall O$

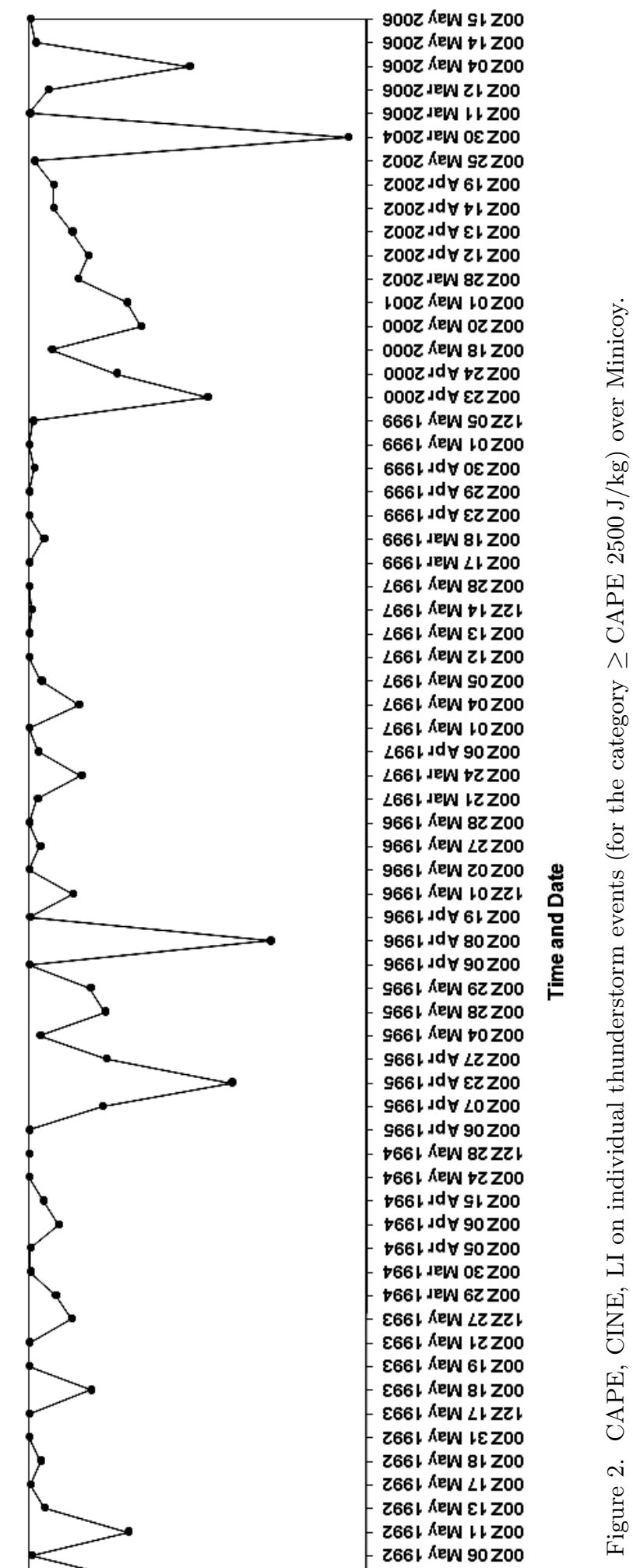

166. Aew GZ

166l AeW $\downarrow Z Z O O$

166। AEW IZZZ

166! AEW 0ZZZI

ᄂ66। Jd $\forall 8 Z Z 00$

l66l Jd $\forall 60 \mathrm{ZOO}$

$166 \mathrm{l} d \mathrm{~d} \forall 80 \mathrm{ZZ}$

a $166 \mathrm{l} d \mathrm{~d} \forall z 0 Z 00$ 


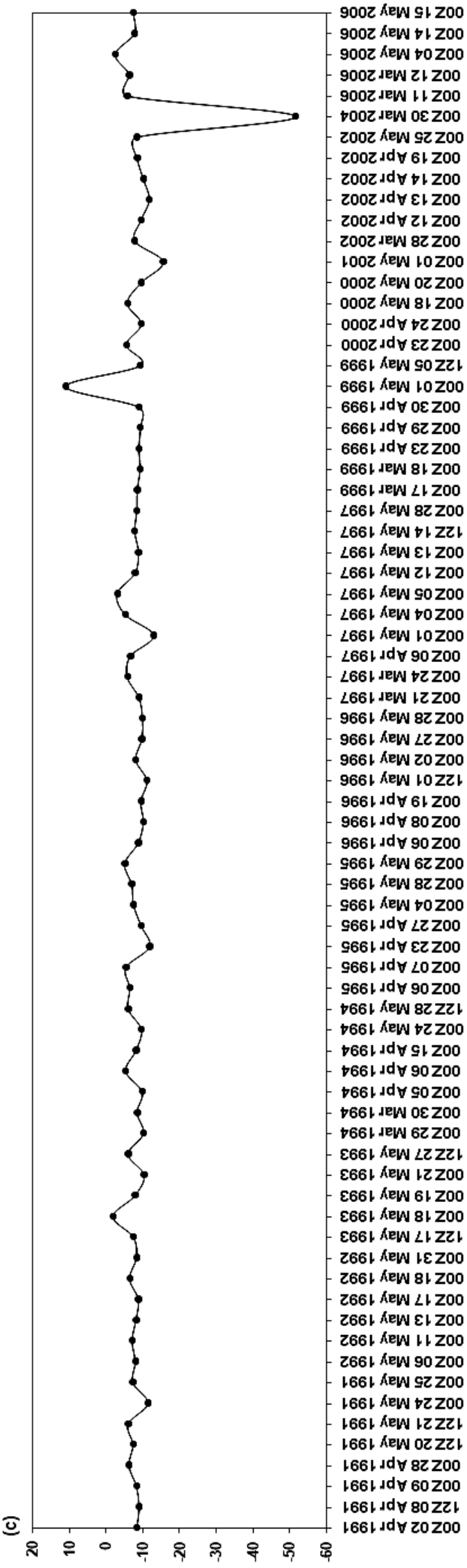

хәриа рәџ!า

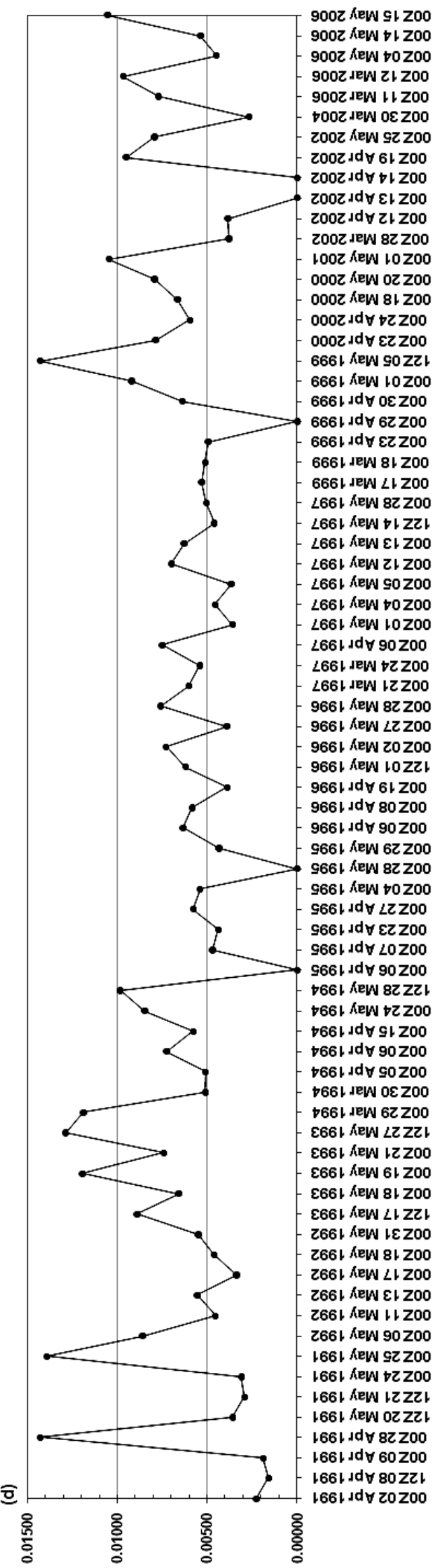

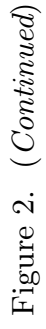


Table 1. Freezing level, precipitable water content (PWC), CAPE (J/kg), CINE (J/kg), LI and average dew point depression $(A D P D)$ during thunderstorm events over Minicoy.

\begin{tabular}{|c|c|c|c|c|c|c|c|c|}
\hline Date & $\begin{array}{c}\text { Hour } \\
\text { (UTC) }\end{array}$ & $\begin{array}{l}\text { Pressure at } \\
\text { the freezing } \\
\text { level }(\mathrm{hPa})\end{array}$ & $\begin{array}{l}\text { Height of freezing } \\
\text { level above mean } \\
\text { sea level }(\mathrm{m})\end{array}$ & $\begin{array}{l}\text { PWC } \\
(\mathrm{mm})\end{array}$ & $\begin{array}{l}\text { CAPE } \\
(\mathrm{J} / \mathrm{kg})\end{array}$ & $\begin{array}{c}\text { CINE } \\
(\mathrm{J} / \mathrm{kg})\end{array}$ & LI & $\begin{array}{c}\text { Average dew } \\
\text { point depression } \\
\text { (approximate value) }\left({ }^{\circ} \mathrm{C}\right)\end{array}$ \\
\hline 8 April 1996 & 1200 & 592 & 4540 & 64.49 & 5788 & -85 & -10 & 2 (upto $175 \mathrm{hPa}$ ) \\
\hline 13 May 1992 & 0000 & 578 & 4700 & 42.35 & 4362 & -5 & -8 & 3 (upto $650 \mathrm{hPa}$ ) \\
\hline 31 May 1992 & 0000 & 551 & 5050 & 45.9 & 4223 & 0 & -8 & 7 (upto $350 \mathrm{hPa}$ ) \\
\hline 6 May 1993 & 0000 & 546 & 5170 & 44.37 & 1483 & 0 & 5 & 6 (upto $726 \mathrm{hPa}$ ) \\
\hline 27 April 1993 & 1200 & 508 & 5800 & 66.24 & 1024 & -46 & -2 & 5 (upto $183 \mathrm{hPa}$ ) \\
\hline
\end{tabular}

Table 2. Observed parameters in the case studies of thunderstorm events over Minicoy.

\begin{tabular}{lcccccccccc}
\hline $\begin{array}{l}\text { Time (UTC) } \\
\text { and date of } \\
\text { observation }\end{array}$ & $\begin{array}{c}\text { LLWS } \\
\text { per km } \\
\left(\mathrm{S}^{-1}\right)\end{array}$ & $\begin{array}{c}\text { ULWS } \\
\text { per km } \\
\left(\mathrm{S}^{-1}\right)\end{array}$ & $\begin{array}{c}\text { VWSD } \\
\text { per km } \\
\left(\mathrm{S}^{-1} \times 10^{-3}\right)\end{array}$ & $\begin{array}{c}\text { CAPE } \\
(\mathrm{J} / \mathrm{kg})\end{array}$ & $\begin{array}{c}\text { CINE } \\
(\mathrm{J} / \mathrm{kg})\end{array}$ & $\begin{array}{c}\text { LI } \\
\text { Rain- } \\
\text { fall } \\
\mathrm{mm}\end{array}$ & $\begin{array}{c}\text { Time of } \\
\text { commence- } \\
\text { ment }(\mathrm{UTC})\end{array}$ & $\begin{array}{c}\text { Time of } \\
\text { cessation of } \\
\text { thderstorm } \\
(\mathrm{UTC})\end{array}$ & $\begin{array}{c}\text { Duration } \\
\text { of thunder- } \\
\text { storm } \\
(\mathrm{h})\end{array}$ \\
\hline 1200 8 April 1996 & 0.00509 & 0.00599 & 90 & 2819 & -121 & -6 & 9.91 & 0931 & 1230 & 1.8 \\
0000 13 May 1992 & 0.00450 & 0.00327 & -1.23 & 4362 & -5 & -8 & 3.3 & 2131 & 0146 & 4.2 \\
0000 31 May 1992 & 0.00508 & 0.00346 & -1.62 & 4223 & 0 & -8 & 66.29 & 1831 & 0131 & 7 \\
0000 6 May 1993 & 0.00325 & 0.00387 & 0.63 & 1483 & 0 & 5 & - & 2131 & 0055 & 3.4 \\
1200 27 April 1993 & 0.00769 & 0.00625 & -1.4 & 1024 & -45 & -2 & - & 0631 & 1001 & 3.5 \\
\hline
\end{tabular}

moderate thunderstorm with hail. The CAPE was found to be $4362 \mathrm{~J} / \mathrm{kg}$ with LI having value of -8 . PWC was $42.35 \mathrm{~mm}$ and rainfall occurred was $3.3 \mathrm{~mm}$. The LCL, LFC and EL were 962.10, 912.43 and $114.58 \mathrm{hPa}$, respectively. The freezing level was $578 \mathrm{hPa}$ at a height of $4.700 \mathrm{~km}$. The clouds were in thick layers $\left(\mathrm{ADPD}=4^{\circ} \mathrm{C}\right)$ with negative VWSD and moderate LLWS and ULWS. The CINE value was also very low $(-5 \mathrm{~J} / \mathrm{kg})$ indicating thereby favourable condition for the development of thunderstorm. Hence the situation was conducive for thunderstorm that lasted for about 4.2 hours. Vertical wind profile (at 0000 UTC 13 May 1992) indicates veering of wind with height, which brings warm air towards the station (figure 3).

Case 3: Thunderstorm of 31 May 1992. This event occurred at 0000 UTC and was reported as heavy thunderstorm without hail but with rain. On this day CAPE was $4223 \mathrm{~J} / \mathrm{kg}$ with an LI of -8. The LCL, LFC and EL were 975.64, 965.47 and $103.84 \mathrm{hPa}$, respectively. The freezing level was $551 \mathrm{hPa}$ at a height of $5.050 \mathrm{~km}$. ADPD was $7^{\circ} \mathrm{C}$ that indicated clouds in thin layers. However, the VWSD was negative with moderate LLWS and ULWS which was conducive for prolonged updrafts and downdrafts leading to thunderstorm for a longer duration. On this day the CINE value was zero which was conducive for the development of thunderstorm. Actually the thunderstorm lasted for 7 hours with heavy rainfall amount

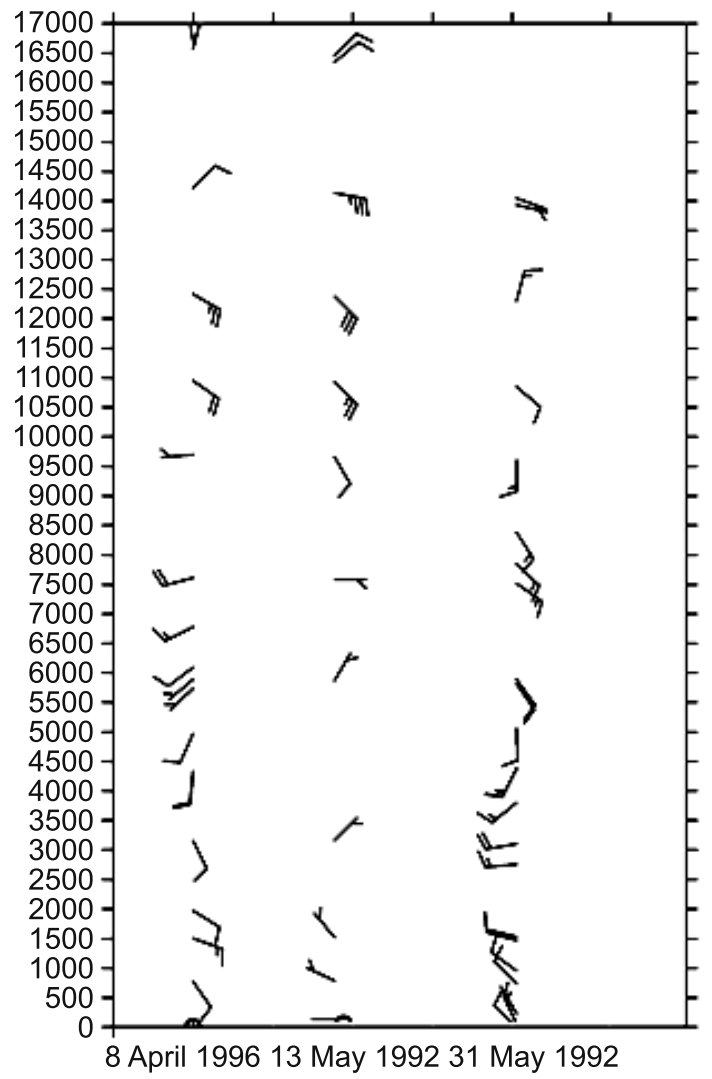

Figure 3. Vertical wind profile at 0000 UTC over Minicoy for thunderstorm events of 8 April 1996, 13 May 1992 and 31 May 1992.

of $66.29 \mathrm{~mm}$ although PWC was $45.9 \mathrm{~mm}$ only. Vertical wind profile (at 0000 UTC 31 May 1992) 
indicates backing of wind with height bringing cold air towards the station (figure 3).

Case 4: Thunderstorm of 6 May 1993. On this day at 0000 UTC, the event was reported as thunderstorm but no precipitation at the time of observation. The CAPE was found to be $1483 \mathrm{~J} / \mathrm{kg}$ with LI having a value of 5 . PWC was $44.37 \mathrm{~mm}$. The LCL, LFC and EL were 959.23, 959.23 and $726.51 \mathrm{hPa}$, respectively. The freezing level was $546 \mathrm{hPa}$ at a height of $5.170 \mathrm{~km}$. The clouds were in thin layers ( $\mathrm{ADPD}=6^{\circ} \mathrm{C}$ ) with positive VWSD and moderate LLWS and ULWS. Low CAPE (i.e., instability) and moderate shears were conducive for long lived (duration $3.4 \mathrm{~h}$ ), non-severe thunderstorm. However, positive VWSD and positive LI suppressed the development of updrafts and cessation of thunderstorm might have occurred between 2131 UTC and 0031 UTC.

Case 5: Thunderstorm of 27 April 1993. This event was reported at 1200 UTC as thunderstorm with or without precipitation. CAPE was $1024 \mathrm{~J} / \mathrm{kg}$ with negative LI of -2 . CINE was found to be $-46 \mathrm{~J} / \mathrm{kg}$. The freezing level was $508 \mathrm{hPa}$ at a height of $5.800 \mathrm{~km}$. ADPD was $5^{\circ} \mathrm{C}$ indicating cloud in thick layers whereas LCL, LFC and EL were $919.27,756.59$ and $183.30 \mathrm{hPa}$, respectively. PWC was $66.24 \mathrm{~mm}$. The duration of thunderstorm was $3.5 \mathrm{~h}$ with time of commencement and cessation between 0631 UTC and 1001 UTC. However, lightning with a duration of $2.75 \mathrm{~h}$ had commenced during the day. High LLWS as compared to ULWS with negative VWSD (at 2 hours past the thunderstorm time) suggest that downburst at the station could have occurred and resulted in LLWS greater than ULWS.

Cases 2 and 3 suggest that the high threshold values of CAPE representing extremely unstable state of atmosphere with negative LI supported by moderate wind shears (LLWS and ULWS) with negative VWSD are conducive for prolonged thunderstorm. If vertical wind shear is extremely weak, updrafts are strongly vertically oriented. When downdrafts develop, it cuts off updrafts resulting in ordinary thunderstorms. Very high vertical wind shear does not allow updrafts to develop deeply. As amount of vertical wind shear increases, updraft tilts enough displacing the precipitation in thunderstorms from developing updrafts and allows longer period storm (multicells) than ordinary thunderstorm. In case 1, where rain occurred at the time of observation, CAPE decreased significantly and positive VWSD suppressed development of thunderstorm. Gilmore and Wicker (1998) have performed sensitivity experiments to see how increasing the magnitude of the vertical wind shear influences downdraft characteristics with $0.008 \mathrm{~s}^{-1}$ (strong) shear instead of $0.005 \mathrm{~s}^{-1}$ (moderate) shear. Case 4 suggests that positive VWSD and sometimes positive LI suppress the development of updrafts in thunderstorms leading to cessation of it. In case 5, whenever rain occurred during thunderstorm and after cessation immediately there is decrease in CAPE value and there is downburst from thunderstorm at the station. This results in LLWS greater than ULWS due to sudden rise in wind and having air parcels cooler. In such a situation, the persistence of wind over the station may be up to 2 hours or more in absence of large scale wind flow pattern.

\subsection{Role of vertical wind shear and $C A P E$ in occurrence of thunderstorms}

The mechanism of vertical wind shear in thunderstorms is presented in this study. The thunderstorm phenomenon consists of three stages of evolution: cumulus, mature and dissipating. Few cases of thunderstorm events (see table 3) where the duration of thunderstorm was covered by the radiosonde/rawin observations taken at Minicoy indicate vertical wind shears change during the three stages. LLWS increases and helps in the development of strong updrafts and moisture supply in cumulus stage. Longer the span of LLWS with moderate to high values, longer is the thunderstorm duration. Without much ULWS, the updrafts are vertically erect and condensation nuclei in cloud growing into ice particles fall through the updraft. The resultant drag and sinking motion enhanced by evaporation cooling, converts updrafts into downdrafts. A sufficient LLWS in mature stage allows updrafts to tilt enough and displace the downdrafts and precipitation from developing updrafts. Thus it allows longer period storm. In the dissipating stage, ULWS increases and suppresses the development of updrafts and thunderstorm thereby ending the storm.

Values of mean vertical wind shear in the layer surface to $700 \mathrm{hPa}$ (LLWS) and $500 \mathrm{hPa}$ to $200 \mathrm{hPa}$ (ULWS) and CAPE at $0000 \mathrm{UTC}$ and 1200 UTC have been computed for thunderstorm cases. However, time evolution of LLWS, ULWS and CAPE from the instant of radiosonde/rawin ascent observation till occurrence of thunderstorm is not known.

\subsection{Development of empirical model to check thunderstorm type and strength and longevity of thunderstorms}

Empirical model is developed based on the results of observational studies of vertical wind shear and instabilities. CAPE is a good indicator of buoyant energy of an air parcel, which would strengthen the 
thunderstorm updraft. Previous studies (Sen 2005) have observed that CAPE greater than $2500 \mathrm{~J} / \mathrm{kg}$ indicate very unstable atmosphere. CINE is important because the atmosphere may be unstable aloft but stable atmosphere may delay or prevent convection in low level. LI is a measure of upper level instability and takes into account elevated convection which tends to occur when upper level disturbances move across unstable equilibrium environment aloft. Negative LI indicates the possibility of convection. Generally vertical speed shear and vertical directional shear are important for the development of thunderstorm.

Our main purpose is to analyze the role of vertical wind shear on strength and longevity of thunderstorms. It is possible only if we compute vertical wind shear during thunderstorm event. From 162 thunderstorm cases, only 72 cases were reported during actual thunderstorm events. These 72 thunderstorm cases are utilized for computation of vertical wind shear. Average of LLWS and ULWS is taken as vertical wind shear in the atmosphere.

As significant percentage of value of vertical wind shear are centered around $0.005 \mathrm{~S}^{-1}$ we categorize vertical wind shear into low $(<0.003$ $\left.\mathrm{S}^{-1}\right)$, moderate $\left(0.003 \mathrm{~S}^{-1} \leq\right.$ vertical wind shear $\left.\leq 0.005 \mathrm{~S}^{-1}\right)$ and high $\left(>0.005 \mathrm{~S}^{-1}\right)$. Figures $1(\mathrm{~d})$ and $2(\mathrm{~d})$ clearly depict the vertical wind shear categorization. Further, vertical wind shear (average of LLWS and ULWS) is implemented for studying strength and longevity of thunderstorm.

The algorithm of empirical model to decide the strength and longevity of thunderstorms is presented in Appendix. The algorithm takes into consideration two thresholds of instability, namely, high $(\mathrm{CAPE}>2500 \mathrm{~J} / \mathrm{kg}, \mathrm{LI} \leq-10$, CINE $>-100 \mathrm{~J} / \mathrm{kg})$ and low $(500 \mathrm{~J} / \mathrm{kg} \leq \mathrm{CAPE} \leq$ $2500 \mathrm{~J} / \mathrm{kg}, \quad$ LI $\geq-5, \quad \mathrm{CINE} \leq-100 \mathrm{~J} / \mathrm{kg}) . \quad$ Figures $1(\mathrm{a}-\mathrm{c})$ and $2(\mathrm{a}-\mathrm{c})$ clearly depict the above categorization. All the cases of CAPE less than $500 \mathrm{~J} / \mathrm{kg}$ have not been taken in to consideration as low values of CAPE do not cause instability and convection.

Low instability and vertical wind shear categorization need to be applied selectively while analyzing the role of vertical wind shear as high shear in atmosphere tears apart the cumulus cloud development resulting in no thunderstorms. The lower limit of low instability, i.e., CAPE has potential for forecasting non-thunderstorm events and needs further examination.

Validation of the model has been performed and presented in table 3. Model was tested for 13 events of five thunderstorm cases and it could detect the thunderstorm stages in all the events. Thus model was successful in determining the strength and longevity of thunderstorms over island station Minicoy. Further, for prolonged thunderstorms high and low instability along with moderate to high vertical wind shear (moderate: $0.003 \mathrm{~S}^{-1} \leq$ vertical wind shear $\leq 0.005 \mathrm{~S}^{-1}$ and high: $>0.005 \mathrm{~S}^{-1}$ ) play a significant role in longevity and strength of thunderstorms.

The model is also tested for Kolkata (coastal station) and results are presented in table 4 . Model is tested for six events of thunderstorm over Kolkata. For brevity, two cases of thunderstorm are discussed here for this coastal station, Kolkata.

Case I: Thunderstorm of 22 May 2003. The event was reported at $1200 \mathrm{UTC}$ as thunderstorm but no precipitation at the time of observation. CAPE was $6935 \mathrm{~J} / \mathrm{kg}$ with an LI of -12 . On this day CINE was $-27 \mathrm{~J} / \mathrm{kg}$. PWC was $71.70 \mathrm{~mm}$ whereas LCL, LFC and EL were 935.54, 889.38 and $101.09 \mathrm{hPa}$, respectively. Rainfall was $26.3 \mathrm{~mm}$. Clouds were in thin layers $\left(\mathrm{ADPD}=7^{\circ} \mathrm{C}\right)$. VWSD was negative with high LLWS and moderate ULWS. It was supported by high CAPE (i.e., positive area tall and thin) which was conducive for prolonged updrafts and downdrafts leading to thunderstorm of longer duration. Actually thunderstorm commenced between 0931 UTC and 1231 UTC with duration of 5.1 hours. It was accompanied by rain and squall.

Case II: Thunderstorm of 14 March 2003. This event was reported at $1200 \mathrm{UTC}$ as thunderstorm with or without precipitation. CAPE was $5576 \mathrm{~J} / \mathrm{kg}$, CINE was $-0.23 \mathrm{~J} / \mathrm{kg}$ and LI was having a value of -9 . Thunderstorm commenced between 1231 and 1531 UTC with a duration of 2.9 hours. It was accompanied by rain and lightning of 2.3 hours duration. PWC was $50.89 \mathrm{~mm}$ whereas LCL, LFC and EL were 952.91, 948.32 and $150.81 \mathrm{hPa}$, respectively. Rainfall was $35.9 \mathrm{~mm}$. Clouds were in thin layers $\left(\mathrm{ADPD}=8^{\circ} \mathrm{C}\right)$. Wind shear in the atmosphere was observed to be higher in this case. In such situations high CAPE (i.e., positive area tall and thin) is indicative of decrease in average magnitude of buoyancy, i.e., suppression of deep development of updrafts and very high vertical wind shear in the atmosphere. If thunderstorm occurs, high vertical wind shear still increases tilting updrafts enough and displacing precipitation in thunderstorms from developing updrafts and allowing longer period storm, i.e., multi-cells to occur.

The analysis for this coastal station shows that extremely unstable atmosphere and vertical wind shear in the atmosphere have to support each other for sustaining supercell. Thunderstorm may occur with high LLWS but its longevity depends on strength of instability. 

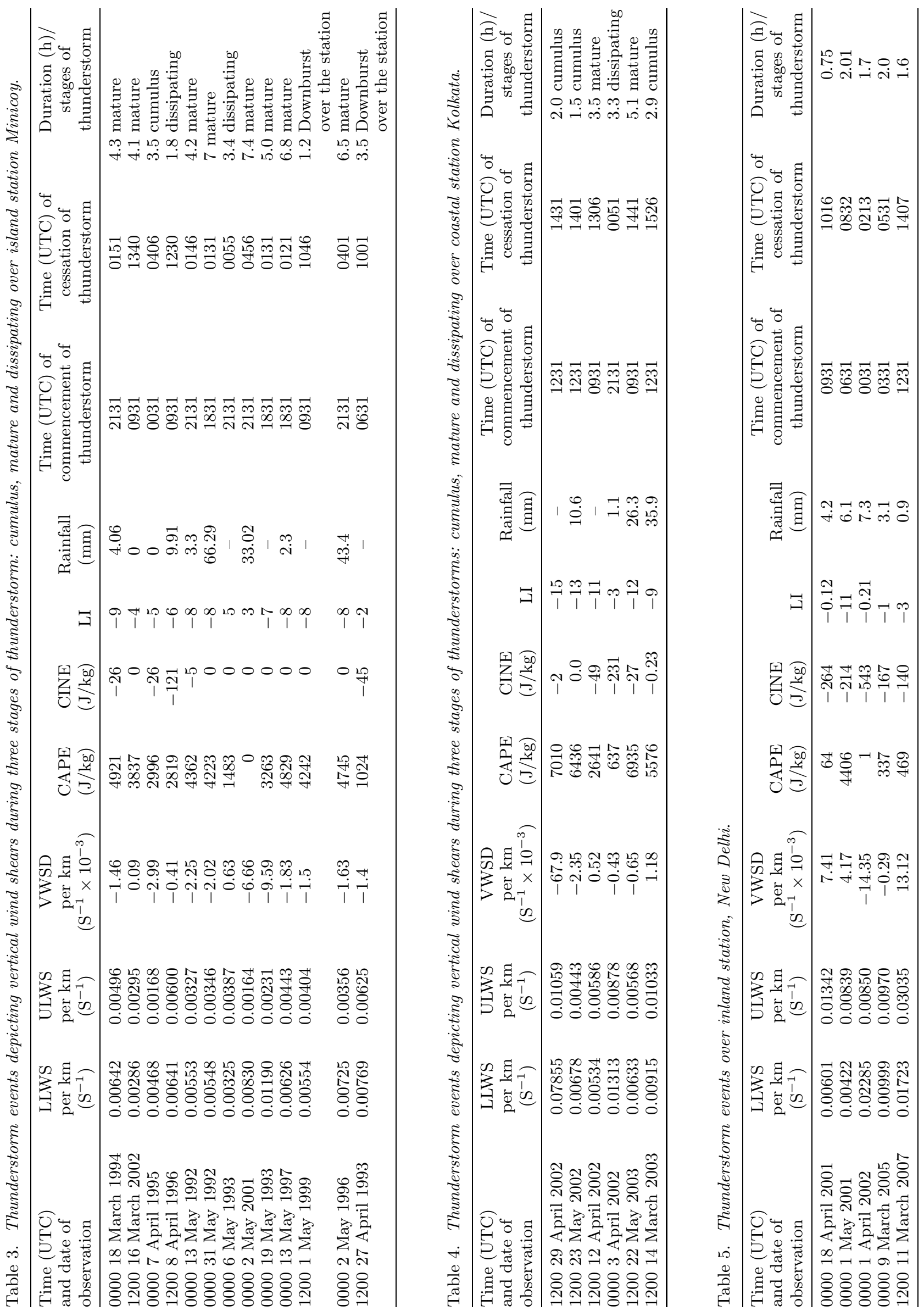
In case of inland stations (e.g., New Delhi), CINE is playing a significant role in thunderstorm activity. Table 5 shows the thermodynamic parameters - CAPE, CINE, LI for thunderstorm over New Delhi. It is seen that CINE reflects strength of capping inversions and it must be overcome and replaced with sufficient CAPE for commencement of convection. High wind shear in the atmosphere could have provided the dynamic forcing to overcome such a high CINE. In tropics, supercells require a higher vertical wind shear relative to the storm updraft (Wibmeier and Goler 2007).

For hill stations like Srinagar, characteristics of thunderstorms are different from those of island and coastal stations. In hill station cases, CINE is found to play a significant role in thunderstorm activity over this region.

The empirical model developed and discussed in this section is valid for island stations and coastal stations. Inland stations and hill stations are excluded from the analysis due to their special characteristics.

\section{Conclusions}

The growth potential and longevity of thunderstorms is decided by CAPE, CINE, LI and mean vertical wind shear in the layer surface to $700 \mathrm{hPa}$ (LLWS) and $500 \mathrm{hPa}$ to $200 \mathrm{hPa}$ (ULWS). The present study suggests that for prolonged thunderstorms high and low instability along with moderate to high vertical wind shear (moderate: $0.003 \mathrm{~S}^{-1} \leq$ vertical wind shear $\leq 0.005 \mathrm{~S}^{-1}$ and high: $>0.005 \mathrm{~S}^{-1}$ ) play a significant role in longevity and strength of thunderstorms. Role of vertical wind shear in thunderstorms and its mechanism is explored in this study. This mechanism was observed in a few cases of thunderstorm events where the duration of thunderstorm was covered by the radiosonde/rawin observations taken at Minicoy. But proper monitoring of LLWS and ULWS during the three stages of evolution of thunderstorm will help us to understand the given mechanism of vertical wind shear in thunderstorms. The empirical model was successful in classifying thunderstorm type for all the cases of thunderstorm events. The empirical model is valid for island and coastal stations.

\section{Acknowledgements}

The authors are thankful to Prof. B N Goswami, Director, Indian Institute of Tropical Meteorology (IITM), Pune and Dr (AVM) Ajit Tyagi, Director General of Meteorology (DGM), India Meteorological Department (IMD), New Delhi. Authors also thank Dr H R Hatwar for giving the encouragement to carry out this work. Special thanks to the University of Wyoming and National Data Centre, IMD, Pune for providing data. Thanks are also due to library staff of IMD and IITM, Pune for their assistance.

\section{Appendix}

Algorithm to decide the strength and longevity of thunderstorms:

Step 1. Input (0000 UTC or 1200 UTC) CAPE, CINE, LI, Wind speed, Wind direction.

Step 2.

a) Calculate $u=$ wind speed $\times \cos ($ wind direction $\left.\times \pi / 180^{\circ}\right)$ $v=$ wind speed $\times \sin \left(\right.$ wind direction $\left.\times \pi / 180^{\circ}\right)$

b) Calculate average vertical wind shear (VWS) per $\mathrm{km}$ : LLWS $=\mathrm{VWS}_{700-\text { surface }}$, ULWS $=$ $\mathrm{VWS}_{200-500}$ by

$$
\mathrm{VWS}_{2-1}=\frac{\sqrt{\left(u_{2}-u_{1}\right)^{2}+\left(v_{2}-v_{1}\right)^{2}}}{z_{2}-z_{1}} \mathrm{~s}^{-1} .
$$

c) Classify LLWS and ULWS as low, moderate or high

$$
\begin{aligned}
& \text { Low }<0.003, \\
& \text { moderate } 0.003 \leq \text { VWS } \leq 0.005, \\
& \text { high }>0.005
\end{aligned}
$$

Step 3.

IF $(\mathrm{CAPE}>2500 \mathrm{~J} / \mathrm{kg}, \mathrm{LI} \leq-10$,

CINE $>-100 \mathrm{~J} / \mathrm{kg})$, then

IF (LLWS, ULWS low), then

Short-lived, severe, thunderstorm

$$
\text { Endif }
$$

Endif

IF $(\mathrm{CAPE}>2500 \mathrm{~J} / \mathrm{kg}, \mathrm{LI} \leq-10$,

CINE $>-100 \mathrm{~J} / \mathrm{kg}$ ) then

IF (LLWS, ULWS moderate), then

$$
\text { Endif }
$$

Long-lived, Severe, thunderstorm

Endif

IF $(\mathrm{CAPE}>2500 \mathrm{~J} / \mathrm{kg}, \mathrm{LI} \leq-10$,

CINE $>-100 \mathrm{~J} / \mathrm{kg}$ ), then

IF (LLWS, ULWS high), then

Endif Supercell

Endif 
$\mathrm{IF}(500 \mathrm{~J} / \mathrm{kg} \leq \mathrm{CAPE} \leq 2500 \mathrm{~J} / \mathrm{kg}, \mathrm{LI} \geq-5$, CINE $\leq-100 \mathrm{~J} / \mathrm{kg})$, then

IF (LLWS, ULWS low), then Short-lived, non-severe thunderstorm Endif

\section{Endif}

IF $(500 \mathrm{~J} / \mathrm{kg} \leq \mathrm{CAPE} \leq 2500 \mathrm{~J} / \mathrm{kg}$, $\mathrm{LI} \geq-5, \mathrm{CINE} \leq-100 \mathrm{~J} / \mathrm{kg})$, then IF (LLWS, ULWS moderate), then Long-lived, non-severe thunderstorm Endif

Endif

IF $(500 \mathrm{~J} / \mathrm{kg} \leq \mathrm{CAPE} \leq 2500 \mathrm{~J} / \mathrm{kg}, \mathrm{LI} \geq-5$, CINE $\leq-100 \mathrm{~J} / \mathrm{kg})$, then

IF (LLWS, ULWS high), then

No thunderstorms

Endif

Endif

\section{References}

Basu G C and Mondal D K 2002 A forecasting aspect of thundersquall over Calcutta and its parameterization during pre-monsoon season; Mausam 53 271-280.

Browning K A and Ludlam F H 1962 Airflow in convective storms; Quart. J. Roy. Meteor. Soc. 88 117-135.

Browning K A 1977 The structure and mechanism of hailstorms; Hail: A Review of Hail Science and Hail Suppression; Meteor. Monogr.; American Meteorological Society $161-43$.

Browning K A 1986 General circulation of middlelatitude thunderstorms; In: Thunderstorm morphology and dynamics; (ed.) Kessler E; Univ. Oklahoma Press, Norman, OK, 133-152.

Byers H R and Braham R R 1949 The thunderstorms, U.S. Govt. Printing Office, Washington D.C., USA, $287 \mathrm{pp}$.

De U S and Dutta S 2005 West coast rainfall and convective instability; J. Indian Geophysics Union 9 71-82.

Galway J G 1956 The lifted index as a predictor of latent instability; Bull. Amer. Meteor. Soc. 37 528-529.

Gilmore S M and Wicker J L 1998 The influence of midtropospheric dryness on supercell morphology and evolution; Mon. Wea. Rev. 126 943-958.
Kandalgaonkar S S, Tinmaker M I R, Kulkarni M K and Nath A 2002 Thunderstorm activity and sea surface temperature over the island stations and along east and west coast of India; Mausam 53 245-248.

Klemp J B 1987 Dynamics of tornadic thunderstorms; Ann. Rev. Fluid Mech. 19 369-402.

Manohar G K and Kesarkar A P 2003 Climatology of thunderstorm activity over Indian region: A study of eastwest contrast; Mausam 54 819-828.

Moncrieff M W and Miller M J 1976 The dynamics and simulation of tropical cumulus and squall lines; Quart. J. Roy. Meteor. Soc. 102 373-394.

Mukherjee A K, Korkhao J M and Srinivasan V 1961 On some sea surface characteristics in relation to storm development over Arabian Sea; Indian J. Meteorol. Geophys. 12598.

Mukherjee A K, Sen P N and Chakrabarty K K 1983 Dependence of diurnal variation of thunderstorm on physical features; Vayu Mandal 13105.

Ranalkar M R and Chaudhari H S 2009 Seasonal variation of lightning activity over the Indian subcontinent; Meteorol. Atmos. Phys. 104 125-134.

Rao D V and Mukherjee A K 1958 On forecasting hailstorms by method of vertical wind changes; Indian J. Meteorol. Geophys. 9 313-322.

Rasmussen E N and Wilhelmson R B 1983 Relationship between storm characteristics and 12 GMT hodographs, low level shear and stability, Preprints, 13th Conf. on Severe Local Storms, Tulsa, OK American Meteorological Society, $55-58$.

Ray Choudhary S N, Subramanian Y H and Chellappa R 1959 A climatological study of storms and depressions in the Arabian Sea; Indian J. Meteorol. Geophys. 10283.

Schneider D and Sharp S 2007 Radar signatures of tropical cyclone tornadoes in central north Carolina; Wea. Forecasting 22 278-286.

Sen P N 2005 Thermodynamics of the atmosphere; Lecture notes of the second SERC school on aviation meteorology, AFAC, Coimbatore, India.

Srivastava A K and Sinha Ray K C 1999 Role of CAPE and CINE in modulating the convective activities during April over India; Mausam 50 257-262.

Weisman M L and Klemp J B 1982 The dependence of numerically-simulated convective storms on vertical wind shear and buoyancy; Mon. Wea. Rev. 110 504-520.

Wibmeier U and Goler R 2007 The influence of vertical wind shear on deep convection in the tropics; Fourth European Conference on Severe Storms, Trieste-Italy.

Williams E and Renno N 1993 An analysis of the conditional instability of the Tropical atmosphere; Mon. Wea. Rev. 121 21-36. 